\title{
Introduction: Reframing Drink and the Victorians
}

The Victorians liked to drink and they lived in a society geared towards alcohol consumption. In the great industrial cities of Britain, there was almost no escaping the beer houses; gin palaces; refreshment rooms; restaurants; theatres; music halls; vaults; dram shops; oyster bars; private clubs and public houses that served a dizzying array of alcoholic drinks to suit people from all walks of life. Drinking went on from dawn till dusk and on into the wee small hours so we know that many people liked to drink. Yet we know very little about their reasons for doing so because the issue of drunkenness has cast a long shadow over the majority of alcohol consumers. In reframing drink and the Victorians, this book looks deeper than the problems of alcohol, to investigate the reasons why people drank it in the first place. It picks up where Brian Harrison's study of the Victorian temperance movement ended and surveys the period from 1869, when the state began to take more control of alcohol regulation and licensing, up until 1914 when wartime regulations were imposed on alcohol sale and consumption. ${ }^{1}$ Harrison's study ended just at the point when the expansion and consolidation of the alcohol industry gave consumers more choice than ever in the types of alcoholic drinks they consumed and in the types of drinking places they frequented. Alcohol became a mass-produced commodity available to an expanding consumer market and this led to heightened political, moral and medical concerns about the problems associated with drinking and drunkenness across towns and cities in Britain.

T. Hands, Drinking in Victorian and Edwardian Britain, https://doi.org/10.1007/978-3-319-92964-4_1 
Many questions about drink and the Victorians remain unanswered but the most pressing relate to how and why the majority of people carried on drinking through a period when it was increasingly difficult to do so in a socially acceptable way. The clues to answering this question lie partly in the substance itself. Alcohol is and was a legal intoxicant that derives its usage and meaning from the social and cultural context in which it is consumed. People share a complex relationship with alcohol that spans time and place but importantly, it is a relationship that involves the agency of consumers. This is why the story of drink in late Victorian and Edwardian Britain resonates today. We live in the consumer society that emerged from late nineteenth century industrial capitalism. The technological advances, production and advertising techniques developed during this time not only turned alcohol into a mass-produced commodity but also gave life to the idea of the consumer. People's drinking behaviour may have been shaped and constrained within a political, medical and moral framework but legislation and public health initiatives only went so far to control drinking behaviour within a political and economic system geared up for mass production and consumption. This is our current dilemma with alcohol and it stems from the late Victorian period. History has shown that it does not matter how often or to what extent alcohol consumption has been problematised or prohibited-people still continue to drink. Therefore, the key to understanding drinking behaviour is to try and understand why people drink. In this regard, the late Victorian period offers the perfect place to start.

Ronald Weir argues that the biggest demon facing the government and the drink trade in Victorian Britain was the 'spectre of the drunkard' which drove the political campaigns of the Temperance movement, shaped legislation and pushed the drink trade into a defensive position. ${ }^{2}$ Early in the century, medical interest in the issue of drunkenness led to the development of the disease concept of inebriety which gained popularity in the 1870s as a means of diagnosing and medically treating heavy drinking and drug use. The British Society for the Study of Inebriety was formed in 1884 by a group of doctors and politicians who campaigned for legislation to legally detain and medically treat inebriates. This resulted in the passing of The Inebriates Act in $1898 .^{3}$

Moral and medical concerns about drunkenness drove political campaigns to reform the licensing system in Britain and in the 1860s the 'drink question' topped party political agendas as a means to win over the electorate. The Liberal Party was broadly aligned with the 
pro-temperance campaigns that sought radical reforms of the licensing system. While in contrast, the Conservative Party sided more with the drink trade in aiming to maintain the status quo and protect the rights of alcohol producers, retailers and consumers. ${ }^{4}$ In response to the tighter alcohol regulations imposed by the 1869 and 1872 Licensing Acts, the drink trade consolidated its efforts to mount political opposition that would challenge legislation and defend the right to buy and consume alcoholic drinks. ${ }^{5}$ At the turn of the century, the stakes were high in the political 'battle' between the state and the drink trade, with the trade facing the prospect of a slow demise and the government facing the wrath of the drinking, pub-going electorate. The main source of debate was over the extent to which the state could legitimately interfere in a private enterprise. The trade was incensed by proposals to directly limit the numbers of pubs; grant more powers to local authorities to limit pub licenses within their districts and remove the profit from selling alcohol by establishing state and local authority run pubs. The 1904 Licensing Act passed by the Conservative government allowed for a reduction in licenses and compensation for the trade. However, as James Nicholls notes, the perceived weakness of this act fundamentally shifted the debate to one of direct state control over the drink trade which seemed unlikely until the outbreak of war in 1914 when the government was forced to take more direct action. ${ }^{6}$

Despite the problems of alcohol, it remained a legal intoxicant and in a recent study, Virginia Berridge considered the reasons why alcohol, unlike other narcotic substances remained legal in Britain. She argues that during the nineteenth century, temperance ideology and the economics of alcohol production were crucial in altering social, cultural and political attitudes towards alcohol. ${ }^{7}$ The consolidation and expansion of the drink trade not only meant that alcohol became a standardised commodity produced for a mass market but it also increased the political influence of the drink trade. In short, the revenue generated from alcohol sales held its own political value. ${ }^{8}$ Therein lies the issue with alcohol: moral and medical concerns about drinking fit uneasily within a capitalist system geared up to cater to an expanding consumer market. Attitudes towards alcohol may have changed but its commodity value remained solid.

Yet this commodity value was largely dependent upon the ability of the drink trade to generate and expand the market for alcohol. This was achieved through the invention of new technology that revolutionised 
the practices of brewers and distillers and allowed for the mass production of beers and spirits. Mid-century improvements in shipping and the expansion of the railways meant that alcohol producers could build the domestic and foreign markets for their products. British imperialism also provided a back-bone for trade by creating military and colonial outlets for alcoholic products. The retail trade expanded after the passing of The 1860 Wine and Refreshment Houses Act which was intended to promote the more 'civilised' habit of wine drinking by allowing the sale of wine and spirits within a wider range of premises. This stimulated the retail trade and led to the growth of refreshment rooms and licensed grocers. It also led to the success of businesses such as The Victoria Wine Company, a retail chain that catered to the more affluent urban middle classes. ${ }^{9}$ This all added up to more choice in what people could drink and where they could drink. Most importantly, Victorians continued to step through the pub door even when the moral, political and medical tide began to turn against alcohol. We know that there was widespread concern about public drunkenness and that efforts were made to tackle this problem. We also know that drunkenness was constructed in religious, political and medical discourse as a moral failing; a medical problem; a source of social and financial ruin; the root of crime and deviance. Yet people still drank alcohol and we really know very little about their reasons for doing so.

\section{Beyond the Spectre of the Drunkard}

One of the ways of looking deeper than the problems of drink is to consider the agency of alcohol consumers. This type of analysis has been used in a number of social and cultural histories of alcohol and other intoxicants. ${ }^{10}$ In a study of Mexican drinking culture, Tim Mitchell views drinkers as rational actors and not 'mere pawns somehow incapable of noticing alcohol's dark side'. He believes that the clues to uncovering people's motivations and drinking behaviour lie at the deeper cultural level. ${ }^{11}$ In a study of cigarette smoking in America, Richard Klein claims that the 'dark, dangerous and sublime' qualities of cigarettes have been erased in a climate of demonization. He argues that cigarettes and smoking have a rich and diverse cultural history that can be explored and understood through a variety of cultural texts without reference to health risks, harm or addiction. ${ }^{12}$ This is a useful methodology for looking at evidence of drinking behaviour because it negates the constant 
need to moralise drinking in the past. For the majority of alcohol consumers, drinking and getting drunk were choices-wilful acts involving the consumption of an intoxicant that held pleasure and meaning. This cannot be ignored or sidestepped by a moralising analysis. To do so would be to deny agency to consumers and disregard the social and cultural significance of a popular legal intoxicant. ${ }^{13}$

Looking beyond the problem framework also requires an understanding of the motives of alcohol producers and consumers. Sociological theories of consumption provide insights into how certain social groups cultivated tastes for particular drinks and how and why needs and desires for specific drinks were generated. Thorstein Veblen's ideas about conspicuous consumption prove useful in considering the drinking behaviour of the middle and upper classes. Veblen argues that the overt display of wealth was one way that the Victorian upper classes could redefine their social class status in a world where consumer goods were becoming more affordable to the masses. ${ }^{14}$ Pierre Bourdieu also considers the links between social class and the practices of consumption but argues that wealth is not enough to define social class status. He uses the concept of cultural capital to explain the ways in which higher levels of education and social etiquette are used by the middle and upper classes to differentiate and reject 'popular' or obvious forms of consumption. ${ }^{15}$

Alcohol consumption must also be considered within the context of the expanding capitalist system. Jean Baudrillard considers the question of how needs for commodities are generated and argues that needs are not somehow 'magically' present within consumer objects. ${ }^{16}$ Instead, the practices of marketing and advertising go further than creating the need to buy specific objects to create the need to buy almost any object. ${ }^{17} \mathrm{In}$ order to circumvent temperance ideology and reach consumers, alcohol producers had to invent reasons to buy alcohol and promote drinking as a desirable activity that symbolised cultural ideals. Michel de Certeau goes further to argue that consumers actively produce rather than consume meanings in objects. ${ }^{18}$ De Certeau is concerned with ordinary people's engagement with consumption which he believes operates in a way that circumvents and subverts the dominant social order. ${ }^{19}$ Building on Michel Foucault's concepts of power and discipline, he proposes that within the grid of discipline that exists to maintain the dominant social order, the 'consumer grid' operates as both a means of social control and political resistance. ${ }^{20}$ In terms of alcohol consumption the relationship between drinkers and drinks may be guided by dominant social and 
cultural norms and values. However, the act of drinking creates a space that holds power for consumers and thus has meaning. The idea of a consumer grid allows agency for consumers to engage with alcohol in different ways for different reasons-sometimes challenging or resisting dominant cultural values.

This book engages with a range of perspectives in order to provide an analysis of alcohol production and consumption between 1872 and 1914. The problems of alcohol were evident during this time but there is another side to the story of drinking in late Victorian and Edwardian Britain. The book is thematically divided into three Parts which deal with different aspects of alcohol production and consumption. Part I explores the ways in which alcohol consumers were imagined and represented in political discourse. Chapter 2 considers the complexities of the drink question in the nineteenth century with an overview of the political responses to the issues of alcohol sale and consumption which resulted in stricter licensing laws later in the century. It then examines the impact this legislation had on alcohol producers and retailers who formed local and national trade defence organisations. One of the ways to promote and protect business interests was through the publication of weekly or monthly trade journals. The main purpose of these journals was to harness interest and support in trade defence activities and to promote and advertise local and national businesses. The chapter examines the ways in which the drink trade endeavoured to 'reinvent' their business as a respectable and vital part of British society. Chapter 3 investigates ideas about the 'great army of drinkers' that continued to drink alcohol despite moral pressure and political control of alcohol sale and consumption. One of the richest sources of information on alcohol consumers lies within the reports of parliamentary enquiries on alcohol held during the second half of the nineteenth century. During these enquiries, witnesses from across Britain gave detailed accounts of drinking within their towns, cities and districts. This provides insights into different types of drinking behaviour and also into the ways in which alcohol consumers were imagined and portrayed.

Chapter 4 continues the analysis of alcohol consumers but shifts the focus on to women drinkers. If men can be defined as a 'great army' of drinkers then women were the 'secret army' whose drinking behaviour was often shrouded by the constraints of gender norms and values or encased in ideas about deviancy and immorality. The chapter considers the division between women's public and private drinking and shows that women's drinking behaviour challenged patriarchal control and the 
ideals of femininity. Chapter 5 examines the issues that surrounded the types of alcoholic drinks sold to the public. It was widely believed that the types and qualities of alcohol sold and consumed within pubs and other drinking places influenced drinking behaviour. The quality of beer, wine and spirits varied enormously and some brewers and publicans used adulterants to enhance the quality, taste or strength of the liquor sold. Strong alcoholic drinks and those adulterated with other intoxicants were believed to have adverse effects on the behaviour of alcohol consumers.

Part II has three case studies of the nineteenth century drink trade. Chapter 6 considers the tactics of the brewing industry by focusing on one of the largest and most successful brewers in Britain, Bass \& Co. Ltd. In order to compete in a growing domestic and foreign market for beer, Bass began to use advertising as a means of reaching larger groups of consumers. By appealing to notions of Britishness and Empire, Bass secured a market for their products and established a strong brand image. The company also used ideas about the supposed health giving properties of beer in order to boost dwindling sales towards the end of the century. Chapter 7 examines the motives of distillers with case studies of two whisky producers, Buchanan and Walker who successfully cultivated a market for Scotch whisky in England. James Buchanan ensured that his company's brands of blended whisky were conspicuously consumed by the British elites through the contract to supply to the Houses of Parliament and by securing Royal warrants. Chapter 8 considers the alcohol retail trade with a case study of one of the leading wine and spirit merchants in the Victorian period, W \& A Gilbey, which restructured its business model due to pressure from customers to supply branded products. In the late Victorian period, particular brands of wine, champagne and spirits became more popular because they were associated with ideas about quality and taste. The company realised that in an emerging consumer culture, the power or 'illusion' of the brand held great commercial profit.

Part III considers the way in which alcohol was used and the different drinking cultures that emerged in the Victorian and Edwardian periods. Chapter 9 considers the use of alcohol by the medical profession in the last quarter of the nineteenth century. This was a time when doctors began to debate the efficacy of alcohol as a therapeutic drug and the moral implications of prescribing alcohol to patients. Alcohol was still used to treat a wide range of psychological and physiological illnesses but debates existed over the issue of therapeutic nihilism-whether alcohol did more harm than good and while some doctors held faith in its 
therapeutic qualities, others disagreed. An analysis of hospital records which show that alcohol use gradually declined in the period leading up to the First World War when the financial and moral cost of alcohol began to impact upon its popularity as a prescribed medicine. Chapter 10 examines the practice of drinking alcohol for health reasons. This was driven in part by the use of alcohol in medical practice but also by commercial factors, which played a significant role in promoting ideas about the health giving benefits of consuming certain alcoholic drinks. The chapter explores the ideas and controversies that surrounded the medicinal use of alcohol through a case study of Wincarnis Tonic Wine, which was one of the leading brands of tonic wine in the late nineteenth century. Political and medical debates existed about the therapeutic value of proprietary tonic wines which were sold and purchased as a means of self-medication for a range of psychological and physiological ailments.

Chapter 11 explores the drinking cultures of the working classes through analysis of oral history interviews conducted in the 1970s on surviving Victorians and Edwardians. These interviews reveal another side to working class drinking, where alcohol consumption revolved around family life, work and leisure. This stands in contrast to the way in which working class drinking was often portrayed as either 'carnivalesque' or 'teetotal' in political discourse. In fact, everyday working class drinking was much more humdrum and routine. In contrast, Chapter 12 considers drinking cultures of the middle and upper classes where there was a desire to consume alcohol in a conspicuous manner in order to reflect and promote social status. One of the key ways of achieving this was to consume the 'right' sorts of drinks in the 'right' kind of places. The chapter considers the way that men and women consumed alcohol within private spaces: in the home and within gentlemen's clubs. The domestic context of alcohol consumption was governed by rules of social etiquette, which both demonstrated and reinforced social class and gender values. The chapter provides a case study of alcohol consumption within two of London's top gentlemen's clubs: The Athenaeum and The Reform Club. The wine committees within gentlemen's clubs were tasked with cultivating and upholding particular standards of taste in alcoholic drinks. The men who drank in the clubs had the freedom and finances that allowed them to do so and therefore they expected to be served only the finest quality alcoholic drinks. As guardians of taste, the wine committees ensured that the alcohol consumed in gentlemen's clubs reflected the class and gender status of club members. 


\section{Notes}

1. Harrison B. 1971. Drink and the Victorians: The Temperance Question in England 1815-1872: London: Faber \& Faber.

2. Weir R. B. 1984. 'Obsessed with Moderation: The Drink Trades and the Drink Question 1870-1930': British Journal of Addiction: Volume 79: pp. 93-107.

3. May C. 1997. 'Habitual Drunkards and the Invention of Alcoholism 1800-1850': Addiction Research: Volume 5:2.

4. Greenaway J. 2003. Drink and British Politics Since 1830: A Study in Policy Making: Basingstoke: Palgrave MacMillan.

5. Gutzke D. 1989. Protecting the Pub: Brewers and Publicans Against Temperance: Suffolk: The Boydell Press; Weir R. B. 1984. 'Obsessed with Moderation'.

6. Nicholls J. 2011. The Politics of Alcohol: A History of the Drink Question in England: Manchester: Manchester University Press.

7. Berridge V. 2013. Demons: Our Changing Attitudes to Alcohol, Tobacco and Drugs. Oxford: Oxford University Press.

8. Berridge V. 2013: location 1673.

9. Briggs A. 1985. Wine For Sale: Victoria Wine and the Liquor Trade 18601984: London: B.T. Batsford Ltd.

10. Duis P. 1998. The Saloon: Public Drinking in Chicago and Boston, 18801920: Chicago: University of Illinois Press; Powers M. 1998. Faces Along the Bar: Lore and Order in the Workingmen's Saloon, 1870-1920: Chicago: University of Chicago Press; Dikotter F., Laarmann L., and Xun Z. 2004. Narcotic Culture: A History of Drugs in China: Chicago, Chicago University Press; Zheng Y. 2005. The Social Life of Opium in China: Cambridge: Cambridge University Press; Heron C. 2003. Booze: A Distilled History: Toronto: Between The Lines; Gately I. 2009. Drink: A Cultural History of Alcohol: New York: Gotham Books.

11. Mitchell T. 2004. Intoxicated Identities: Alcohol Power in Mexican History and Culture: London: Routledge: p. 6.

12. Klein R. 1993. Cigarettes Are Sublime: London: Duke University Press.

13. Klein R. 1993: p. 2.

14. Veblen T. 1889/1994. The Theory of the Leisure Class: New York: Dover Publications Inc.

15. Bourdieu P. 1984/2010. Distinction: A Social Critique of the Judgment of Taste: London: Routledge.

16. Baudrillard J. 2003. 'The Ideological Genesis of Needs', in (eds.) Clarke D. B., Doel M., and Housiaux K. The Consumption Reader: London: Routledge: pp. 255-259.

17. Baudrillard J. 2003: p. 256. 
18. de Certeau M. 2003. 'The Practice of Everyday Life', in (eds.) Clarke D. B., Doel M., and Housiaux K. The Consumption Reader: London: Routledge: pp. 259-267.

19. de Certeau M. 2003: p. 259.

20. de Certeau M. 2003: p. 260.

Open Access This chapter is licensed under the terms of the Creative Commons Attribution 4.0 International License (http://creativecommons.org/licenses/ by $/ 4.0 /)$, which permits use, sharing, adaptation, distribution and reproduction in any medium or format, as long as you give appropriate credit to the original author(s) and the source, provide a link to the Creative Commons license and indicate if changes were made.

The images or other third party material in this chapter are included in the chapter's Creative Commons license, unless indicated otherwise in a credit line to the material. If material is not included in the chapter's Creative Commons license and your intended use is not permitted by statutory regulation or exceeds the permitted use, you will need to obtain permission directly from the copyright holder.

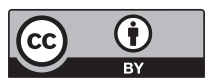

